\title{
Elusive Pursuit of Reconciliation and Development in Post-Apartheid South Africa
}

\section{Vusi Gumede}

University of Mpumalanga, South Africa
Article DOI:

https://doi.org/10.35293/srsa.v42i2.77

\section{Abstract}

Debates on whether reconciliation is taking place and particularly the issue of inclusive development continue in South Africa. Reconciliation is understood as a process whereby different population groups in South Africa peacefully coexist and restore amicable relations which were fractured by colonialism and apartheid. Inclusive development has to do with the socio-economic transformation that involves, or rather benefits all the peoples of a country. Socioeconomic transformation is considered slow since the dawn of democracy, with nation-building, development, freedom, and related objectives having suffered in post-apartheid South Africa. The notions of justice and inclusivity require comprehensive analysis, especially many years after the formal end of apartheid in 1994. The paper examines development and reconciliation, in seeking an explanation for what appears to be a changing political landscape in South Africa, epitomised by the decline in the number of votes that the governing party, the African National Congress (ANC), is receiving since 2009 while the Economic Freedom Fighters, a relatively new party, is gaining traction. It is argued that the slow pace of inclusive development and weak reconciliation are compromising the ANC, resulting in the evolution of the political landscape in South Africa. Essentially, the inability to improve reconciliation has resulted in weak inclusive development and makes it difficult for South Africa to become a nation.

Keywords: reconciliation; development; freedom; justice; democracy; nationbuilding. 


\section{Introduction}

The changing political landscape in South Africa, as epitomised by changes in the results of the last three national general elections and the last two municipal (local government) elections, merits attention as it suggests that the observed changes would result in a different political landscape, from the 2021 municipal elections onwards. Problems in the African National Congress (ANC) are exacerbating its decline. The ANC, or its influence or popularity, has been in decline because it has not been able to advance inclusive development and it is failing to lead reconciliation, among other issues.

To consider the extent to which inclusive development and associated factors have been attended to since 1994, this paper focuses on the changing political landscape. Inclusive development has to do with the socio-economic transformation that involves, or rather benefits all the peoples of a country. The changes in the political landscape, with increasing erosion of the ANC power base, derives from the view that inclusive development has been slow while reconciliation has been weak. The ANC received 62.5\% of votes in 1994 and 69.7\% in 2004 (Twala 2014). The Independent Electoral Commission (IEC) of South Africa estimates a $7.4 \%$ decline in the number of votes received by the ANC between 2014 and 2019, while the Economic Freedom Fighters (EFF) grew by almost 70\% during 2014-2019 (albeit from a low base). The ANC garnered $62.2 \%$ of the votes in 2014, while the EFF had 6.4\%. In 2019, the ANC had 57.5\% of the votes during the general election and EFF had 10.8\%.

It is indeed insightful that the Democratic Alliance's share of the vote declined by $6.6 \%$ while the Freedom Front Plus (FF+) gained substantially during 2014 and 2019. The FF+ had 0.9\% of total votes in 2014 and it received 2.4\% for 2019, making it the fifth-largest party in Parliament though its share of votes is not significant. Arguably, this has to do with the land question because the $\mathrm{FF}+$ has been explicit in defending white farmers against expropriation of land without compensation, while the DA had not been clear enough about its standpoint. Regarding local government elections, there was a decline of about 8\% in the ANC's share of votes during the 2011 and 2016 local government elections, the ANC had attained 61.9\% of votes in 2011 (Twala 2014). This trend implies that the ANC could continue getting less and fewer votes in future. In the 2021 municipal elections, the ANC might not get substantial votes while 
other political parties, especially the EFF, could grow substantially. This is largely because the ANC has not governed well.

The focus of this paper is inclusive development and reconciliation as well as freedom and justice, to some extent. The challenge with an undertaking such as this relates to the starting point for the analysis. Some could argue that the way 'development' has been conceptualised is problematic, particularly the neoliberal notions of development. Under the neoliberal agenda, there is minimal government involvement in the lives of individuals and society - as opposed to Marxist notions of development, which have to do with overall material conditions. This view (associated with Marxism) suggests that when development occurs this inevitably precipitates freedom and justice. The stance is that freedom and justice, as well as development, are not an abstraction but the essence of the same material conditions. The Marxist viewpoint considers it problematic to discuss development, freedom, and justice as separate issues.

The paper starts with a brief background and then deals with the theoretical and conceptual issues, which are followed by a broad review of the performance of the economy, and societal progress in the twenty-six years since political independence. Before concluding, the paper discusses justice, freedom, and development in the context of reconciliation. It is worth highlighting other related issues, such as human rights and needs, which this paper does not cover. The central point which this paper makes is that socio-economic inclusion has been weak so far and reconciliation has not been effective in post-apartheid South Africa. The main argument is that this weak socio-economic inclusion and poor reconciliation have unleashed a significant change in the political landscape of South Africa.

\section{Freedom, Reconciliation and Development}

Hamilton (2014) theorises extensively about development and freedom in the South African context. However, Hamilton leaves out justice from his analysis. He appears to have deliberately done this; hence he concludes that 'all South Africans are not free. In the context of 'apartheid colonialism' and the South African political transition from apartheid to 'democracy' a more persuasive argument could be that it is the African (Black) population group that is not entirely free in South Africa. 'Apartheid colonialism' is used as shorthand for 
the centuries of a discriminatory system of colonialism and decades of systemic social and economic exclusion of the majority in South Africa. Hence, what is needed is a fundamental restructuring of the whole of South African society that can make 'all' South Africans (equally) free (see Gumede 2018). The paper however recommends policy interventions that can advance socio-economic transformation because the fundamental transformation of the South African society is not easy given the very nature of the South African society and also because that will take a long time.

South Africa experienced about 350 years of regimes that oppressed the majority Africans by the minority white population group. A few years before the democratic dispensation, the cold war ended and that limited possibilities for the road South Africa could take. However there were many efforts and initiatives aimed at reconciliation, reconciling the white population group and Africans. South Africa was a deeply divided society along racial lines before democracy. It could not be considered a nation. At the dawn of democracy and the first decade of democracy witnessed various initiatives aimed at reconciliation. South Africa remains a deeply divided society with many socio-economic challenges. Both reconciliation and development have been elusive. The governing ANC has not succeeded in ensuring reconciliation and the pace of socio-economic transformation has been slow.

The conception of development which this paper adopts is that development involves socio-economic progress or improvements in the well-being of people. Development must involve the people that need development. The people should be able to guide the development needed and also have choices for their livelihoods as Sen (1999) or Ake (2000) would put it, or as Escobar (1995) discusses development. The improvements in wellbeing are widely quantified through the Human Development Index (HDI) which measures human development as a composite indicator made up of life expectancy, literacy, and per capita income. For South Africa, the debate about development must also deal with social and economic inclusion, which also covers reconciliation, justice, and freedom.

Manganyi (2004) explains that freedom and democracy were important objectives considered for South Africa's development agenda as South Africa transitioned from apartheid to democracy. This paper concludes that development has suffered. Also, as explained later, an argument is advanced that South Africa has drifted further away from a 'nation' that was initially envisaged. 
The nation referred to is the notion of 'Rainbow Nation', which could happen if reconciliation and development take place. The South African 'Rainbow Nation' could be viewed as a community of all South Africans co-existing and working towards a common future. The common future in question should arguably involve the sharing of resources and an appropriate balance of power and influence among all racial groups in South Africa.

Focusing on freedom, another way of thinking about freedom is to consider political freedoms in addition to development as freedom covered in the works of Claude Ake, Amartya Sen and John Rawls. Pertaining to justice, both economic and social justice are viewed by Ake, Sen and Rawls as linked to both freedom and development - the same can be said about distributive justice. The paper prefers the term 'inclusive justice' which entails both freedom and development.

The works of Barry (1996), Rawls (1971) and Sen (1999) on justice are not helpful for the South African or African context. Interestingly, in response to criticisms of his theory of justice, Rawls (1999: 3) says that "a theory however elegant and economical must be rejected or revised if it is untrue". Part of the problem with Rawls theory is that many countries in Africa are faced with structural inequalities which are ramifications of colonialism: it is hard to apply a 'veil of ignorance' because the real 'original position' for all Africans is known. There is yet to be sound theorisation about justice in the context of South Africa or Africa broadly. In the context of Latin America or the global south broadly, Dussel (2006) has gone a long way in theorising justice and freedom.

Linked to freedom and justice is the issue pertaining to nation-building and/or social cohesion in the context of the national question because social cohesion or nation-building is linked to reconciliation. As Gumede (2008: 9) puts it, "nation-building is a process aimed at ensuring cohesion among different peoples in a particular nation-state." Social cohesion is understood as the extent to which a society is functional, united, and coherent as well as ensuring space for citizens to make choices they value. In South Africa, it should therefore be more meaningful and relevant to see a nation - a product of nation-building and or social cohesion - as a community that, among other things, "acknowledges and respects its repulsive political and economic history of deprivation through systematic restitution, reconciliatory and restructuring measures and, more importantly, equitable sharing of resources" (Gumede 2016: 44). It is in this context that South Africa still seems far from becoming a nation. The pursuit 
of reconciliation should have taken the fundamental of nation-building into account, as there must be an appropriate balance of power and influence among all people and or cultural groups in South Africa- essentially, a nation.

The literature on the notion of a nation and or the national question implies that it is difficult to make up a nation or for a nation to exist, even as efforts to imagine a nation are pursued as Anderson (2006) theorised. Stalin (1973: 60), for instance, defined a nation as "a historically constituted, stable community of people, formed based on a common language, territory, economic life, and psychological make-up manifested in a common culture." Tilly (1975: 6), on the other hand, highlighted that "nation remains one of the most puzzling and tendentious items in political lexicon." Given what leading scholars view to be a nation, it was always going to be difficult for South Africa to become a nation. From the perspective of a 'Rainbow Nation', as explained earlier, it can be argued that South Africa has drifted further away from becoming a nation.

The failure of reconciliation and poor inclusive development have made it even harder to conceive of an appropriate balance of power and influence among all people and or cultural groups in South Africa. It may be useful to highlight that there are debates about the idea or notion of a nation (as discussed in Gumede 2016). In short, some of the leading thinkers (for example, Aimé Césaire and Kwesi Kwaa Prah) reject the very notion of the term of a nation while other leading thinkers (for example, Sam Moyo and Samir Amin) embrace the term. The concept of a nation can be useful in analysing socio-economic transformation, as Patricia McFadden and others have done in the context of South Africa. This paper cautiously embraces the notion of a nation with a view that it would be important to have an appropriate balance of power and influence among all people and or cultural groups in South Africa, hence the importance of reconciliation. This view is influenced by the theorisation of or about a nation by Benedict Anderson.

Anderson (2006: 8) defines a nation as "an imagined political communityand imagined as both inherently limited and sovereign... the nation is always conceived as a deep, horizontal comradeship." For South Africa, the post-apartheid 'nation' was imagined as a 'Rainbow Nation'. The view that South Africa is drifting away from becoming a nation is in this context, the 'Rainbow Nation' is turning out to be a façade largely because reconciliation seems to be failing. The South African society appears unable to achieve the 'deep and horizontal comradeship' 
that Anderson (2006) views as critical for a society to become a nation.

As Sarkin (2001) indicates, striking a balance between reconciliation and justice during transitions from conflict-ridden tyrannical regimes to democratic or inclusive systems can be approached in two ways; pursuing criminal trials and/ or by instituting truth and reconciliation processes. According to Sarkin (2001), implementing one of the strategies instead of both may lead to negative results. An ideal situation is where both strategies are employed. Lived experiences and material conditions of ordinary Black South Africans bear testimony to the assertion that little has changed on the socio-economic justice front, and many relations between Black and White South Africans are still, to a large extent, determined by the hierarchical apartheid architecture (LenkaBula 2005).

Assessing the efficacy of the South African Truth and Reconciliation Commission (TRC), LenkaBula (2005) is of the view that many South Africans are fearful that the TRC was too focused on forgiveness of the perpetrators of apartheid atrocities. This was done at the expense of justice for those whose loved ones were maimed and killed, and this has inadvertently compromised social and economic justice in post-apartheid South Africa. The role of economic or distributive or restorative justice was downplayed or outright neglected by both the TRC and subsequently the ANC, and its officials in government over the years since 1994.

Gobodo-Madikizela (2003: 128) puts it, "when perpetrators express remorse... they are revalidating the victim's pain - in a sense giving his or her humanity back." In other words, the victim may become empowered by this, in that he or she may accept or reject the perpetrator's remorse and the victim "becomes the gatekeeper to what the outcast [perpetrator] desires - readmission into the human race" (Gobodo-Madikizela 2003: 117). Gobodo-Madikizela (2003: 118) raises one of the fundamental questions: "The question is not whether victims can forgive 'evildoers' but whether we - our symbols, language, and politics, our legal, media, and academic institutions - are creating the conditions that encourage alternatives to revenge."

Her view is that if memory is kept alive to cultivate old hatred and resentments, it is likely to culminate in vengeance and repetition of violence. But if memory is kept alive to transcend hateful emotions, then remembering can be healing (Gobodo-Madikizela 2003). It is a complex issue. It is indeed critical that memory in the context of South Africa can be used to advance nation-building. Memory, 
also in terms of heritage, can be an instrument for healing and bringing about a 'Rainbow Nation' that Archbishop Desmond Tutu hoped for. Arguably, all population groups should better co-exist and share in the country's resources. In addition, incidences of racism and white supremacy attitudes must be done away with. Essentially, those who commit racial 'crimes' must be brought to book.

The South African Constitution and its potential use as an instrument towards the realisation of inclusive development and in achieving (economic) freedom, justice, reconciliation, and national unity is another political dynamic that has in recent years gained much traction. Modiri (2018) devotes a lot of time wrestling with these questions from a legal perspective and prefers to conceptualise apartheid as colonial conquest because this helps to (re)imagine different ways of addressing its legacy in contemporary South Africa. Modiri, (2018: 316) contends that "the failure to redress the structural continuity of colonial-apartheid renders the constitution's extension of universal suffrage, citizenship and human rights to Black people hollow and abstract.”

The dialectics between race, class, and gender have for decades and even centuries been debated by scholars from different schools of thought and ideological inclinations. Marxists make a case that injustices are perpetuated mainly through class contradictions. Decolonial scholars, pan-Africanists, and Critical Race Theorists make a case that race is a determinant factor in many socio-economic and political upheavals in the world. Feminists on the other hand see patriarchal oppression as the main challenge in women struggles.

Hassim (2018) reflecting on the gender equality clause in the South African Constitution makes a case that it has some aspects of radical roots emanating from (Black) women struggles in the 'racial-capitalist South Africa'. Hassim (2018: 343) argues that "the equality clause in the Constitution is a product, albeit imperfect, of a century-long history of struggles by black women, sometimes in concert with other oppressed social groupings, and sometimes in tension with them." In essence, the point Hassim (2018) is making is that, contrary to some 'radical' voices who see the constitution as a bourgeoisie capitalist Western project, she views it is as a product of local people's struggles (especially Black women in this instance) and that it was not necessarily imposed from the West.

As hypothesised earlier, it is highly likely that the ANC is losing votes because it has not been able to lead regarding land and agrarian reforms. Increasingly, many in the African population group have become disgruntled with what 
seems to be indecisiveness on the part of the ANC. The EFF has been decisive on the land question. While the DA has not been vigorously against the calls for expropriation without compensation the $\mathrm{FF}+$ has been, hence the increase in the share of votes that went to the FF+ in the 2019 general elections. Arguably, various wars of dispossession, ANC's formation in 1912 and other formations in South Africa had one central goal which was to reclaim the stolen land of Africans since the arrival of white colonial settlers in 1652. There has, however, in the last ten years or so been a reinvigoration around the land question especially amongst younger people in South Africa as the fault lines of the negotiated settlement are increasingly laid bare and many people are disillusioned (LenkaBula 2005). It is in this context that an argument is advanced that the ANC is losing more votes, or its votes are shifting to the EFF.

Gibson (2009) predicted that the unresolved land question in South Africa was like a 'tinderbox' waiting to explode and we are currently seeing that beginning to unfold with the increased land 'invasions' and evictions happening across the country. Indeed, as Vorster (2019) argues, land reform, restitution and redistribution continue to be the most contentious and divisive socio-political issue in South African contemporary politics. The land question will continue to shape the political landscape in South Africa. It is arguably more significant than corruption and other dynamics that affect sentiment towards the ANC. The EFF is also viewed as corrupt by some, but it seems some of those who have been voting for the ANC are increasingly voting for the EFF. The pricing and tender scandals associated with interventions to mitigate the negative impact of the coronavirus have bedevilled both the ANC and the DA, although corruption in the ANC has been going on for much longer.

All in all, as More (2011) would put it, there has not been decolonisation in South Africa because true decolonisation must ensure that indigenous South Africans have control over the country and enjoy necessary freedoms. Linked to this is the issue of land which largely remains in the hands of the minority in South Africa. Also, there are psychosocial issues that remain unresolved, manifested in occurrences such as sporadic attacks on so-called foreign nationals and genderbased violence as prominent cases. The predominantly racialised inequality that still characterises South Africa also bears testimony that development still has a long way to go. 


\section{South Africa's socio-economic performance}

Post-apartheid South Africa has generally been performing below par, particularly in the economic sphere, notwithstanding that the size of the economy has grown substantially since 1994 . The economy stabilised from the early 2000s, but South Africa's economic performance has been pedestrian relative to many comparable countries. The coronavirus has worsened an already fragile socio-economic performance. The economy was in recession when the coronavirus impacted South Africa. Human development, as measured by the Human Development Index (HDI), has also not improved much since 1994 - it was worse before 1994. In short, the HDI, which is a composite of indicators on life expectancy, education and access to resources needed for a decent living, is used to quantify wellbeing globally.

Other challenges are facing South Africa, particularly concerning poverty and inequality. It may be useful to briefly discuss these two - mainly focusing on money metric aspects (i.e. income inequality and income poverty). South Africa has largely experienced positive economic growth rates since the mid1990s, however, the impact of this growth on reducing inequality inherited from apartheid has been disappointing (Visagie 2013). Income inequality has remained high due to the structure of the economy of South Africa (Gumede 2015).

Arguably, income inequality remains stubbornly high because the number of jobs created by the economy barely kept pace with the growth of the economically active population (Statistics South Africa 2019). Unemployment remains between 25 and 35 per cent, depending on whether one counts as being unemployed discouraged workers who have given up looking for a job (Statistics South Africa, 2016). The situation is also compounded by the fact that the social transfers system caters only for children from poor households, the elderly and people with disabilities. Income inequality, therefore, remains very high because of wage inequalities in the labour market, and the wide gap between those who are employed and those who are unemployed (Leibbrandt et al 2009; van der Berg et al 2008). It is expected that wage inequalities are going to be worse due to the coronavirus pandemic as more people become unemployed. As Table 1 shows, the mean and median income shares by population group in 1993 and 2008 continue to differ significantly by population group. 
Table 1: Mean and median income comparison by population group, 1993 $\& 2008$

\begin{tabular}{|l|l|l|l|l|}
\hline \multirow{2}{*}{ Population group } & \multicolumn{2}{|l|}{ Mean income $(\mathbf{R})$} & \multicolumn{2}{l|}{ Median income (R) } \\
\cline { 2 - 5 } & 1993 & 2008 & 1993 & 2008 \\
\hline African & 539 & 816 & 304 & 367 \\
\hline Coloured & 1072 & 1381 & 795 & 800 \\
\hline Indian & 2148 & 4288 & 1430 & 1860 \\
\hline White & 4632 & 6275 & 3418 & 4188 \\
\hline Total & 1147 & 1456 & 419 & 450 \\
\hline
\end{tabular}

Source: Adapted from Leibbrandt et al (2012)

Mean income is the amount obtained by dividing the total aggregate income of a group by the number of units in that group (which is the average). The median income is the amount that divides the income distribution into two equal groups, half having income above that amount and half having income below that amount. There was a 51.4 per cent increase in mean income during 1993-2008 for the African population group. The mean income for Africans was R539 in 1993 and R816 in 2008. The Coloured population experienced a 28.8 per cent increase in mean income during the same period. The figures were 99.6 per cent for the Indian population and 35.5 per cent for the white population. Table 1 also shows, through the mean income, that the Indian population was the biggest beneficiary of income distribution since the dawn of the democratic dispensation during 1993-2008.

The picture is slightly different when one investigates the median income. There was a 20.7 per cent increase in median income for the African population. The figures were 0.6 per cent increase for Coloureds, 30.1 per cent increase for Indians and a 22.5 per cent increase for Whites. Once again, the Indian population is the biggest beneficiary in terms of the increase in median income and Coloureds fared the worst.

Looking at household income by gender and population group from the 2012 Income and Expenditure Survey, as shown in Table 2, the African population 
group accounted for 44.6 per cent of the income in 2012, Coloureds accounted for 9.9 per cent, Indians for 5.4 per cent and Whites for 40.1 per cent.

Table 2: Annual household income by gender and population group of household head, 2012

\begin{tabular}{|l|l|l|}
\hline Head of household & $\begin{array}{l}\text { Rand amount } \\
\text { (in millions) }\end{array}$ & Proportion (\%) \\
\hline All households & 1567455 & 100.0 \\
\hline Gender & & \\
\hline Male & 1201714 & 76.7 \\
\hline Female & 365741 & 23.3 \\
\hline Population group & & \\
\hline Black/African & 699154 & 44.6 \\
\hline Coloured & 154730 & 9.9 \\
\hline Indian/Asian & 84495 & 5.4 \\
\hline White & 629075 & 40.1 \\
\hline
\end{tabular}

Source: Based on Statistics South Africa's IES, 2012

There was also a significant disparity in the distribution of income in terms of the gender of the household head. Male-headed households accounted for 76.7 per cent of the income share while female-headed households accounted for 23.3 per cent of the total income. By implication, comparing Tables 1 and 2 , the distribution of income appears to have been largely stagnant during the democratic period in South Africa, particularly in the 2000s.

In the most recent period, it is interesting to observe that all population groups derive most of their income from work. However, not surprisingly, households headed by whites derive a greater share of the income from capital than other population groups. The white population group received 3.6 per cent of their total income from capital. On the other hand, Africans derived 9.6 per cent of their total income from pensions, social insurance, and family allowance. Although this is understandable given the fact that Africans as a group do not 
own much by way of income-generating assets, it is curious that this has not changed even in 2017.

Recent data (e.g. annual income by population group) based on Statistics South Africa's Living Conditions Survey) confirm that income of Africans from work relative to the other population groups was approximately half, a third and a quarter of the Coloured, Indian, and Whites from work, respectively. Indeed, as Sulla and Zikhali (2018: 65) indicate, "race is a strong predictor of poverty, and the chronically poor group is almost exclusively made up of Black and Coloured South Africans."

Using the National Income Dynamics Study (NIDS), a longitudinal study collecting data in almost 30,000 households started by government in 2006 and housed at the University of Cape Town for the period 2008-2012, Gumede and Biyase (2016: 72) concluded that "average earnings of white (R17,592) and Indian/Asian $(\mathrm{R} 12,164)$ population groups are markedly higher than the average monthly average earnings of their Coloured (R5,298), and Black African (R4,144) counterparts." Race is therefore not only a strong predictor of poverty but a strong marker for many things, including the level of income, job opportunities etc.

Poverty remains extremely high in South Africa as many estimates indicate. The challenge of poverty in South Africa is multidimensional, as in most parts of the developing world. Poverty in South Africa is structural - it is the structure of the economy that perpetuates poverty through its capital intensity, mineralenergy-complex character, and high-skill demand in the labour market (Gumede 2018). The estimates based on the National Income Dynamics Study (NIDS) confirm that poverty affects the African population group and females more, although overall poverty had been declining before the coronavirus pandemic.

As Table 3 indicates, although poverty rates have been declining (for the period with suitable data), the African population group has a higher share of those in poverty and females as far as gender is concerned to have higher poverty rates compared to males. 
Table 3: Poverty rates by race and gender

\begin{tabular}{|l|l|l|l|l|l|}
\hline Race & 2008 & 2010 & 2012 & 2014 & 2017 \\
\hline African & $56 \%$ & $54 \%$ & $46 \%$ & $37 \%$ & $33 \%$ \\
\hline Coloured & $31 \%$ & $24 \%$ & $20 \%$ & $16 \%$ & $19 \%$ \\
\hline Asian/Indian & $8 \%$ & $7 \%$ & $3 \%$ & $1 \%$ & $2 \%$ \\
\hline White & $0.5 \%$ & $0.9 \%$ & $1 \%$ & $0.8 \%$ & $2 \%$ \\
\hline Male & $44 \%$ & $41 \%$ & $35 \%$ & $28 \%$ & $26 \%$ \\
\hline Female & $52 \%$ & $49 \%$ & $42 \%$ & $35 \%$ & $32 \%$ \\
\hline
\end{tabular}

Source: Own calculations based on NIDS, various issues

With the COVID-19 pandemic, there will be more Africans and more females plunging into poverty. The level of poverty has likely been increasing since 2018 due to the worsening poor economic performance of the South African economy, the increase in unemployment and stagnant per capita incomes.

South Africa's economic growth over the years derives from capital-intensive sectors and very few jobs have been added to the labour market. There is also a widely held view that a mismatch exists between the kinds of job opportunities available in the economy and the skills of most job seekers. Twala (2011) for example, argues that the South African economy has not been creating enough jobs for the unskilled and semi-skilled labourers who are concentrated mostly in the townships and rural areas. Thus, in the context of continued weaknesses in South Africa's education and training system, there has been limited success in efforts to absorb a significant portion of the unemployed population (Gumede 2011).

The role of education in one's prospects, including prospects for getting a job, cannot be debated. For instance, Statistics South Africa's Income and Expenditure Surveys and the Living Conditions Survey show a decline in poverty with rising levels of education. According to Sulla and Zikhali (2018: 41),

In 2015,73.1 per cent of the population living in households whose head did not have a formal education, versus 2.6 per cent of those living in 
households whose head had attained education beyond upper secondary school were poor. Between 2006 and 2015, the population living in households with heads who had completed primary school experienced the fastest decline in poverty. Similar patterns are true for individuals: in 2015, 55.0 per cent of individuals with no formal education were poor compared to 2.6 per cent of those who went beyond upper secondary school.

Having a higher level of education is accompanied by a lower risk of poverty, as argued by Sulla and Zikhali (2018). With regards to employment prospects, Gumede and Biyase (2016) make a point that education does not only improve prospects of getting a job but also results in relatively better earnings. There are also geographic differences in levels of income. Gumede and Biyase (2016: 72) found that, between 2008 and 2012, "average earnings are considerably higher in urban areas, at R6,351 compared to R3,335 and R3,582 in traditional and farm areas."

In addition to income inequality and poverty, race remains a persistent fault line in South Africa's unemployment trends. The continuing decline in the labour force participation rate is indicative of an increase in the number of discouraged jobseekers. South African youth remain disproportionately affected by unemployment compared to the adult population and the same holds for females relative to their male counterparts (Statistics South Africa 2019). The unemployment rate was already very high before the coronavirus pandemic.

South Africa is further faced with the complexities relating to an uneven labour market environment, the changing nature of work, lack of labour market measurement instruments, and that of serving a multi-class of service beneficiaries: vulnerable workers and unemployed/job-seekers. The fragmented nature of South Africa's labour market, increasing informality, 'casualisation' and externalisation of the labour market has undoubtedly worsened the job crisis and affected the economic status of ordinary working-class people. It is in this context that some have argued that South Africa needs labour market reforms and or a clear labour market policy (Gumede 2015). In the meantime, the initiatives such as the labour market incentive schemes should be expedited to ameliorate the youth unemployment challenge. The proposed labour market reforms and or a clear labour market policy should prioritise job creation for the African 
population group. In the main, however, the fundamental issue has to do with restructuring the South African economy (see Gumede 2016).

\section{Development and the Changing Political Landscape}

In the 2009-2019 period, there has been a relatively significant decline in the ANC's share of total votes. Changes in the election results overtime imply a change in the political landscape in South Africa. Table 4 shows the said decline in the votes that the ANC received during 2009-2019: from 65.1\% in 2009 to $57.5 \%$ in 2019 (at a national level). The largest declines in the votes going to the ANC were in Mpumalanga province, while the number of votes that the ANC received in the Eastern Cape remained similar for both 2009 and 2019.

Table 4: Election results

\begin{tabular}{|l|l|l|l|l|l|l|l|l|l|}
\hline & \multicolumn{3}{|l}{2009} & \multicolumn{2}{l|}{2014} & \multicolumn{2}{l|}{2019} \\
\hline & ANC & DA & COPE & ANC & DA & EFF & ANC & DA & EFF \\
\hline Gauteng & 64,0 & 21,9 & 7,8 & 53,6 & 30,8 & 10,3 & 50,2 & 27,5 & 14,7 \\
\hline & & & & & & & & & \\
KwaZulu-Natal & 62,9 & 1,3 & 9,1 & 64,5 & 12,8 & 1,8 & 54,2 & 13,9 & 9,7 \\
\hline Eastern Cape & 68,8 & 13,7 & 9,9 & 70,1 & 16,2 & 3,5 & 68,7 & 15,7 & 7,8 \\
\hline Free State & 71,1 & 11,6 & 11,6 & 69,8 & 16,2 & 8,1 & 61,1 & 17,6 & 12,6 \\
\hline Northern Cape & 60,8 & 16,7 & 12,6 & 64,4 & 23,9 & 5,0 & 57,5 & 25,5 & 9,7 \\
\hline North West & 72,9 & 8,3 & 8,3 & 67,4 & 12,7 & 13,2 & 61,9 & 11,2 & 18,6 \\
\hline Limpopo & 84,9 & 7,5 & 3,5 & 78,6 & 6,5 & 10,7 & 75,5 & 5,4 & 14,4 \\
\hline Mpumalanga & 85,5 & 2,9 & 7,5 & 78,2 & 10,4 & 6,3 & 70,6 & 9,8 & 12,8 \\
\hline Western Cape & 31,6 & 7,7 & 51,5 & 32,9 & 59,4 & 2,1 & 28,6 & 55,4 & 4,0 \\
\hline National & 65,1 & 16,7 & 7,3 & 61,4 & 22,9 & 6,3 & 57,5 & 20,8 & 10,8 \\
\hline
\end{tabular}

Source: Based on the Independent Electoral Commission (various sources)

The DA gained during 2009 and 2014 but lost some ground in 2019. In 2014 
the DA received 22.9\%, and in 2019 it received 20.8\% nationally. In 2014 the EFF received 6.3\%, and in 2019 it received 10.8\% nationally. The analysis focuses on the 3 biggest political parties hence Table 4 does not include other political parties.

Many seasoned scholars and activists have argued that part of the challenge South Africa faces has to do with the transition from apartheid to the postapartheid (democratic) dispensation. This transition has been characterised by some scholars as the elite transition or elite compromise or reform bargain. Bond (2011) and Terreblanche (2012), for instance, characterise the transition from apartheid to democracy as an elite transition. In other words, elites agreed on the nature and the outcome of the transition from apartheid to a democratic society. Southall $(2010,5)$ explains reform bargain as a "mechanism that facilitated South Africa's success which was underpinned by the new government's commitment to providing the opportunities for large-scale business to internationalise." In other words, a compromise was reached to allow big businesses, which were traditionally white-owned and remain significantly owned by whites, to access opportunities in South Africa and elsewhere.

On the more radical side, Saul (2012) argues that no significant changes have occurred in South Africa because the economy is still subject to the control and manipulation of the global capitalist system. Linked to what Saul (2012) says, it can be argued that the post-apartheid dispensation has become a compromise between the African majority and the white minority because the whites have remained with significant control of the economy (Gumede 2016). It is in this context that others argue that South Africa needs a new political settlement, something along the lines of a social pact or a social contract (Habib 2013).

In the broad African context, many scholars have examined the socioeconomic transformation of the continent and conclude that the developing world (and Africa in particular) faces the development merchant system challenge (Adedeji 2002). The development merchant system is effectively the hegemony of the West on Africa that makes it difficult for Africa to do things on its own. The development merchant system ensures a deliberate design by the global capitalist order to perpetuate a socio-economic and political system that advances the interests of the West and maintains the peripheralisation of the African continent.

Lastly, part of the development challenges confronting South Africa relates to 
the relations between the private sector and the government (see Gumede 2018). The government appears to be captured by the private sector, or state-capital favours profits over people, as Chomsky (1999) would put it. It is in this context that political inequality and political patronage have caused a rift between the political leadership and the people in general. The many public protests and confrontations between the police and the people are symptomatic of the challenge epitomised by skewed state-capital relations.

Inclusive development has given way to personal enrichment by those closer to political power or those in political office. We are dealing with a case of 'incomplete liberation' as Saul (2012) puts it. Hamilton (2014) concludes that South Africa is a case of 'revolution still pending' while Habib (2013) concludes that South Africa is a case of 'suspended revolution.' On the other hand, it might very well be - judging from the frequency and the violent character of protests - that the revolution has started. The coronavirus pandemic is coming across as a catalyst: sooner than later discontent can result in a widespread uprising. The inability of the government to advance socio-economic transformation has resulted in a changing political landscape, with corruption worsening the situation.

\section{Reconciliation, Justice and Freedom}

As many have argued, the first decade or so of democracy in South Africa was about putting in place a foundation that could have helped South Africa better advance social and economic development (see, for instance, Manganyi [2004]). In hindsight, indeed, it was wise of Nelson Mandela to focus primarily on reconciliation and nation-building. The most important transformation agenda of the post-apartheid South Africa, especially during the years of the Government of National Unity, had to be peacebuilding.

However, despite attempts by the Truth and Reconciliation Commission (TRC) to achieve catharsis from the ills of the past, limited honest and remorseful acknowledgement of the evils of the apartheid regime have continued to spur revolutionary pressures from the previously disadvantaged group. Qunta (2016) argues that the TRC did not deal with the institutional aspects of the atrocities committed by the apartheid regime, for instance. In other words, only individuals were expected to account but not the apartheid system. Valji (2015), for instance, 
argues that the TRC's failure to deal with the issue of race was an 'ironic silence' because economic discrimination and various forms of human rights violations were motivated by racism. Among other issues, Mamdani (2000,59) views the use of a Latin American commission's design as problematic because "the Latin American analogy obscured the colonial nature of the South African context: the link between conquest and dispossession, between racialised power and racialised privilege, between perpetrator and beneficiary."

As discussed earlier, Gobodo-Madikizela (2003) holds a view that the TRC was useful particularly as it allowed "perpetrators [to] express remorse ... revalidating the victim's pain - in a sense giving his or her humanity back" (p128). The jury is still out, even after two decades of democracy, whether the victim's pain has been revalidated. Many of the 'perpetrators' have not shown much remorse as confirmed by many continued incidences of racism. There are even instances where the beneficiaries of the apartheid system say apartheid was better than democracy.

The 2013 South African Reconciliation Barometer report by the Institute of Justice and Reconciliation (IJR) on the perceptions of South Africans regarding issues related to progress since 1994 presents interesting results - many survey respondents felt that many aspects of 'freedom' have worsened since 1994. Relative to those that feel there are improvements, more feel that insufficient employment opportunities have been created, and the gap between the rich and poor has worsened. 36.7 per cent feel that the gap between the rich and poor has worsened, compared to 30.3 per cent of those that feel that the gap has improved.

Arguably, the perception of inequality matters greatly and has a greater influence than numbers alone may suggest. Overall, 42.1 per cent felt that employment opportunities have worsened, relative to 31.1 per cent who felt that employment opportunities have improved. These perceptions speak volumes: the sense that any of the aspects of 'freedom' has worsened since 1994 is an indictment on the pursuit of justice and freedom. Notwithstanding, it is encouraging that some feel that there are improvements in the various areas since the advent of democracy in South Africa. Arguably, there would be more people who would feel that there are no or very little improvements if the survey were to be done again.

For a country with centuries of apartheid colonialism, reconciliation and peacebuilding can be a lifetime process. The success of the TRC or its failures 
remains a matter of contention. Juxtaposed with the Convention for a Democratic South Africa (CODESA) negotiations, the TRC played a far more important role as Gobodo-Madikizela (2003) and others argue. CODESA can be said to have largely left white privilege - although not white domination per se unchanged (Meintjies 2013). The TRC had an important role in peacebuilding, although it did not fully achieve its noble objective. The recent report by the Institute for Justice and Reconciliation as captured in Wale (2014) explains that:

The relationship between race and class in South Africa paints a picture of class segregation with racial inflexions. The majority of the poor continue to be black and segregated from the multiracial, urban middle class. This pattern is witnessed on the geographical landscape of South Africa, where our cities may demonstrate increasing racial integration, but townships and rural settlements continue to be poor, black and segregated as was intended by apartheid planners. This finding is important for racial reconciliation in South Africa and points to the need to address the relationship between material and social exclusion that results in the segregation of many poor black South Africans from interracial middle-class city spaces.

The position of Wale (2014) and others points to an issue that is not widely spoken about: incorrect or inaccurate theorisation about apartheid colonialism and associated factors. To a large extent, as argued and elaborated in Gumede (2016), socio-economic development has been constrained by policy failure in South Africa. In particular, the policy failure in question involves incorrect theorisation or theories that gave precedence to non-racialism. The fundamental developmental challenge required that Africans be prioritised in the postapartheid development agenda. The overemphasis on non-racialism blurs the historical experience of apartheid colonialism. The preoccupation with nonracialism discounts the fact that Africans suffered historical injustices of apartheid colonialism of which the ramifications are still pronounced even close to three decades of political independence.

Two areas where theories need to be revisited are The National Democratic Revolution (NDR) and the Colonialism of a Special Type (CST). Regarding the CST, Chaloult \& Chaloult (1979) and Hudson (1986), among others, published 
papers critiquing the CST thesis and suggesting that it was not an appropriate characterisation of South Africa even in the 1950s/1960s. In addition, Visser (1997) argued that the CST thesis would easily impress any person with little knowledge about South Africa because it obscures rather than explains the South African conundrum. As for the NDR, South Africa appears stuck in the bourgeois democracy phase - the first stage of the NDR. As Hudson (1986) predicted, national (bourgeois) democracy would most likely lead to a consolidation of capitalism rather than a transition to socialism. Although the NDR appears to be a robust aspiration of the ANC, more work must be done to make it a reality because it increasingly looks like it has become a pipedream.

Reconciliation, as argued earlier, viewed in the context of South Africa as focused on restitution, reconciliation, restructuring and the equitable sharing of resources. It should be vigorously pursued. Inclusive development cannot be effective without proper reconciliation in the context of South Africa. Put differently, development would remain precarious without reconciliation. More efforts should be made to create a South African nation in the true sense. The inability of the ANC to deal with these issues has resulted in many concerns with the ANC, resulting in the power base of the ANC increasingly declining.

\section{Conclusion}

The point that this paper makes is that weak reconciliation and poor inclusive development have, during the past ten years or so, resulted in significant changes in the political landscape in South Africa. It is also in this context that the paper argues that South Africa is drifting further away from becoming a nation. By implication, more efforts should be pursued regarding nationbuilding, particularly by ensuring inclusive development. Because South Africa has not directly addressed the historical injustice (i.e. apartheid colonialism), reconciliation remains a pipedream - and so too is development. Consequently, justice and freedom for the majority remain compromised. It is therefore not surprising that the EFF is gaining traction and that the ANC is losing its share of votes. This is a sign that reconciliation and development have not been satisfactorily addressed since 1994 . The coronavirus pandemic has worsened an already fragile socio-economic situation.

To take the South African society forward, in the meantime, comprehensive 
policies are needed, over and above improving implementation, as well as monitoring and evaluation and planning. There are many areas that require policies. For instance, South Africa still requires comprehensive social and economic policies. And there are areas that require policy reforms. Of course, leadership and partnerships are critical. This paper focuses on policy issues, hence the emphasis regarding the types of policies needed to take the society forward and to achieve its objectives as captured in the Constitution. Of course, fundamentally, there has to be reconfiguration of the South African society as a whole in the longer term. 


\section{References}

Adedeji, A (2002), "From the Lagos Plan of Action to the New Partnership for Africa's Development and from the Final Act of Lagos to the Constitutive Act, Wither Africa." Keynote address to the African Forum for Envisioning Africa, Nairobi, Kenya.

Ake, C (2000), Democracy and development in Africa. Maryland: Brookings Institution.

Anderson, B (2006), Imagined Communities: Reflections on the Origin and Spread of Nationalism. London and New York: Verso.

Barry, B (1996), Justice as Impartiality: A Treatise on Social Justice. London: Clarendon Press.

Bond, P (2011), “South African splinters: from 'elite transition' to 'small alliances' ", Review of African Political Economy, Vol 38, No 127, pp 113-121.

Chaloult, N and Y Chaloult (1979), "Internal Colonialism Concept: Methodological Considerations", Social and Economic Studies, Vol 28, No 4, pp 85-99.

Chomsky, N (1999), Profit over People: Neoliberalism and Global Order. New York: Seven Stories Press.

Dussel, E (2006), Twenty Thesis in Politics. North Carolina: Duke University Press. Escobar, A (1995), Encountering Development: The Making and Unmaking of the Third World. Princeton: Princeton University Press.

Gibson, J L (2009), Overcoming Historical Injustices. Land Reconciliation in South Africa. New York: Cambridge University Press.

Gumede, V (2008), "Policy Making in the Post-apartheid South Africa - A Preliminary Perspective." Africanus: Journal of Development Studies, Vol 3, No 2, pp 7-23.

Gumede, V (2011), "Public Sector Reforms and Policymaking: A Case of Education in an Emerging Developmental South Africa”, In Sayed, Y; Kanjee, A and M, Nkomo(eds). The Search for Quality Education in Post-apartheid South Africa. Pretoria: HSRC Press, pp 33-41.

Gumede, V (2014), “The Millennium Development Goals: Towards a Post-2015 Development Agenda for South Africa, In Nyoka, A and Hofmeyr, J (eds). Breaking the Mould: Prospects for Radical Socio-economic Transformation. Cape Town: Institute for Justice and Reconciliation, pp 45-58. 
Gumede, V (2015), Political Economy of Post-apartheid South Africa. Dakar: CODESRIA Press.

Gumede, V (2016), Post-apartheid South Africa: Economic and Social inclusion. New York: Cambria Press.

Gumede, V (2017), "Presidencies and Policy in Post-apartheid South Africa," Politeia, Vol 36, No 1, pp 1-17.

Gumede, V (2018), "Rethinking Socio-economic Policies and State-capital Relations in South Africa, In Gumede, V (eds), Inclusive Development in Africa: Transforming Global Relations. Pretoria: AISA, pp 187-204.

Gumede, V and Biyase, M (2016), "Educational Reforms and Curriculum Transformation in Post-apartheid South Africa", Environmental Economics, Vol 7, Issue 2, pp 69-76.

Gobodo-Madikizela, P (2003), “A Human Being Died that Night." Claremont: David Philip.

Habib, A (2013), South Africa's Suspended Revolution: Hopes and Prospects. Johannesburg: Wits Press.

Hart, G (2013), Rethinking the South African crisis: Nationalism, Populism and Hegemony. Scottsville: UKZN Press.

Hamilton, L (2014), Are South Africans free? London: Bloomsbury.

Hassim, S (2018), "Decolonising Equality: the Radical Roots of the Gender Equality Clause in the South African Constitution." South African Journal on Human Rights, Vol 34, No 3, pp 342-358.

Hudson, P (1986), "The Freedom Charter and the Theory of National Democratic Revolution." Transformation, Vol 1, pp 6-38.

Leibbrandt, M.V. and Woolard, I (2012), "Describing and Decomposing Postapartheid Income Inequality in South Africa", Development Southern Africa, Vol 29, No 1, pp 19-34.

LenkaBula, P (2005), "Justice and Reconciliation in Post-Apartheid South Africa: A South African Woman's perspective", International Review of Mission, Vol 94, No 372, pp 103-116.

Mamdani, M (2000), "A Diminished Truth", in James, W and L Van de Vijver (eds). After the TRC: Reflections on Truth and Reconciliation in South Africa. Cape Town: David Phillip.

Manganyi, C (2004), On becoming a Democracy: Transition and Transformation in South African Society. Pretoria: UNISA Press. 
Mbembé, A (2001), On the postcolony. Berkeley: University of California Press. Meintjies, F (2013), "The TRC and CODESA failed South Africa: It's Time we Reflected on this." (Available at: http://sacsis.org.za/site/article/1783, accessed 21 July 2020).

Modiri, JM (2018), "Conquest and Constitutionalism: first Thoughts on an Alternative Jurisprudence", South African Journal on Human Rights, Vol 34, No 3, pp 300-325.

Ndlovu-Gatsheni, S (2012), "Coloniality of power in development studies and the impact of global imperial designs on Africa, An Inaugural Professorial Lecture, University of South Africa, Pretoria, 16 October.

News24 (2012) "Outrage over FW de Klerk Comment. 11 May. (Available at: http://www.news24.com/SouthAfrica/Politics/Outrage-of-FW-de-Klerkcomments-20120511, Accessed 2 June 2020).

Qunta, C (2016), Why We are Not a Nation. Cape Town: Sereti Sasechaba Press. Rawls, J (1971), A Theory of Justice. Boston: Harvard University Press.

Sarkin, J (2001), "The Tension between Justice and Reconciliation in Rwanda: Politics, Human rights, Due Process and the Role of the Gacaca courts in Dealing with the Genocide." Journal of African Law, Vol 45, No 2, pp 143-172. Saul, J (2012), "Globalisation, Recolonisation and the Paradox of Liberation in Southern Africa", in Lissoni, A; Soske, J; Erlank, N; Nieftagodien, N and O Bashda (eds). One Hundred Years of the ANC: Debating Liberation Histories Today. Johannesburg: Wits Press, pp. 76-82.

Sen, A (1999), Development as Freedom. New York: Anchor.

Southall. R (2010), "South Africa from Short Term Success to Long Term Decline", in Daniel, J; Naidoo, P; Pillay, D and R Southall (eds), New South African Review: Development or Decline? Johannesburg: Wits University Press, pp 1-21. Stalin, J (1973), “Marxism and the National Question”, Works, Moscow, 2: 300-381 StatsSA (2019), "Quarterly Labour Force Survey (QLFS), 1st Quarter 2020." (Available at: http://www.statssa.gov.za/?page_id=1854\&PPN=P0211, accessed 09 July 2020).

Sulla, V and P Zikhali (2018), "Overcoming Poverty and Inequality in South Africa : An Assessment of Drivers, Constraints and Opportunities." Washington, D.C.: World Bank Group. (Available at: http://documents.worldbank.org/curated/ en/530481521735906534/Overcoming-Poverty-and-Inequality-in-SouthAfrica-An-Assessment-of-Drivers-Constraints-and-Opportunities, accessed 12 
June 2020).

Terreblanche, S (2012), Lost in Transformation: South Africa's Search for a New Future since 1986. Sandton: KMM Review.

Twala, C (2014), "The Historical Significance of the African National Congress (ANC) Election Campaigns 1994-2014: A Genuine Process of Political Liberalisation", Mediterranean Journal of Social Sciences, Vol 5, No 7, pp 562 -568 .

Tilly, C (1975), "Western State Making and Theories of Political Transformation", in Tilly, C (ed.), The Formation of National States in Europe. Princeton: Princeton University Press.

United Nations Development Programme (UNDP). (2013), "Human Development Report.” New York: Palgrave Macmillan.

United Nations Development Programme (UNDP).(2019)"Human Development Report.” Technical notes. (Available at: http://hdr.undp.org/sites/default/files/ hdr2019_technical_notes.pdf, accessed 8 July 2020).

Valji, N (2004), "Race and Reconciliation in post-TRC South Africa." A Paper Presented at a Conference Entitled Ten Years of Democracy in Southern Africa. The Southern African Research Centre. Canada, Queens University, 2014. (Available at: https:/www.csvr.org.za/publications/1648-race-andreconciliation-in-a-post-trc-south-africa, accessed 21 July 2020).

Van der Berg, S (2008), "How Effective are Poor Schools? Poverty and Educational Outcomes in South Africa, Studies in Educational Evaluation, Vol 34, No 3, pp 145-154.

Visser, N (1997), "Post-coloniality of a Special Type: Theory and its Appropriation in South Africa”, The Yearbook of English Studies, Vol 27, pp 79-94.

Wale, K (2014), "Reflecting on Reconciliation: Lessons from the Past, Prospects for the Future." Cape Town: Institute for Justice and Reconciliation. 